\title{
Glassy spherules from the Cretaceous-Paleogene boundary interval in the Bąkowiec section (Skole Nappe, Polish Outer Carpathians)
}

\author{
Jolanta Dąbek, Patrycja Wójcik-Tabol \\ Institute of Geological Sciences of the Jagiellonian University \\ ul. Gronostajowa 3a, 30-387 Cracow \\ Email addresses: \\ jolantadabek95@wp.pl \\ p.wojcik-tabol@uj.edu.pl
}

\begin{abstract}
:
Mass extinction in the Cretaceous-Paleogene boundary, which took place about $66 \mathrm{Ma}$, is well known almost to everybody because of the extinction of the largest prehistorical reptiles, which have ever walked on the Earth, i.e. the dinosaurs. For scientists this event is important because of the possible meteorite impact. Evidences of extraterrestrial material interference are searched since this argument was ever made. The most desirable evidences, which can be find in the CretaceousPaleogene boundary sediments are: iridium anomaly, shocked minerals and glassy spherules. The Bąkowiec section (SkoleNappe of the Polish Outer Carpathians) was studied. Glassy spherules, which was separated from the sediment, were divided into four typesdue to their chemical compound. We distinguish carbonate, ferrous, silicate and apatite spherules.
\end{abstract}

Key words: Cretaceous-Paleogene boundary, mass extinction, flysch, glassy spherules, Polish Outer Carpathians 
Introduction:

The phenomenon of mass extinctions at the boundary of the Cretaceousand Paleogene, which took place about $66 \mathrm{Ma}$ is an issue that is still interesting for scientists. This extinction is the most famous event of this type in the Earth's history. During the Cretaceous extinction, about $75 \%$ of plants and animals species died out. The mass extinction resulted in that the most-known prehistoric reptiles, dinosaurs, pterosaurs, mosasaurs and plesiosaurs and also Inoceramus bivalves and ammonites disappeared. The cause of the extinction made this event so popular. About $66 \mathrm{Ma}$ a collision of a huge cosmic body with the surface of the Earth's surface initiated all kinds of events which had caused considerable damage and significant limited life conditions [2].

Evidences of collision are still searched [1] [6]. The most desirable traces are: Besides of meteorite rocks and craters, iridium anomaly, shocked quartz and glassy spherules are the most desirable traces of cosmic impact.

The Earth's rockscontain traceamounts of iridium and other elements from the platinum group (about $0.05 \mathrm{ppb}$ ) [10]. The Cretaceous/Paleogene boundary (CPB) rocks show the concentration of $\mathrm{Ir}$ higher 30 to even 120 times than normally, probably because of extraterrestrial contribution [1].

The combination of high temperature and pressure can generate very different types of deformations. The shocked quartz is distinguished by special lamellae that can be seen in microscopic magnification. The features are narrow $(1-2 \mu \mathrm{m})$ and crossed [8].

Another important proof of impact are spherules that were created when the meteorite hit the Earth and melted the rocks[4]. Spherules are usually spherical, less than $1 \mathrm{~mm}$ in diameter. Though they may take lenticular, tearful or hantelike forms [6]. Spherules can be made of amorphous or crystal matter. They cannot contain elements that occur in meteorites in large accumulation, e.g. Ir [3]. Spherules of volcanic or anthropological origin may contain the $[\mathrm{OH}]{ }^{-}$groups, contrary to the meteoritic particles [8].

Geological background

Samples were collected from the CPB sediments in the Bąkowiec section (SE Poland, the Podkarpacie province, NW from Husów village). [Fig.1] 


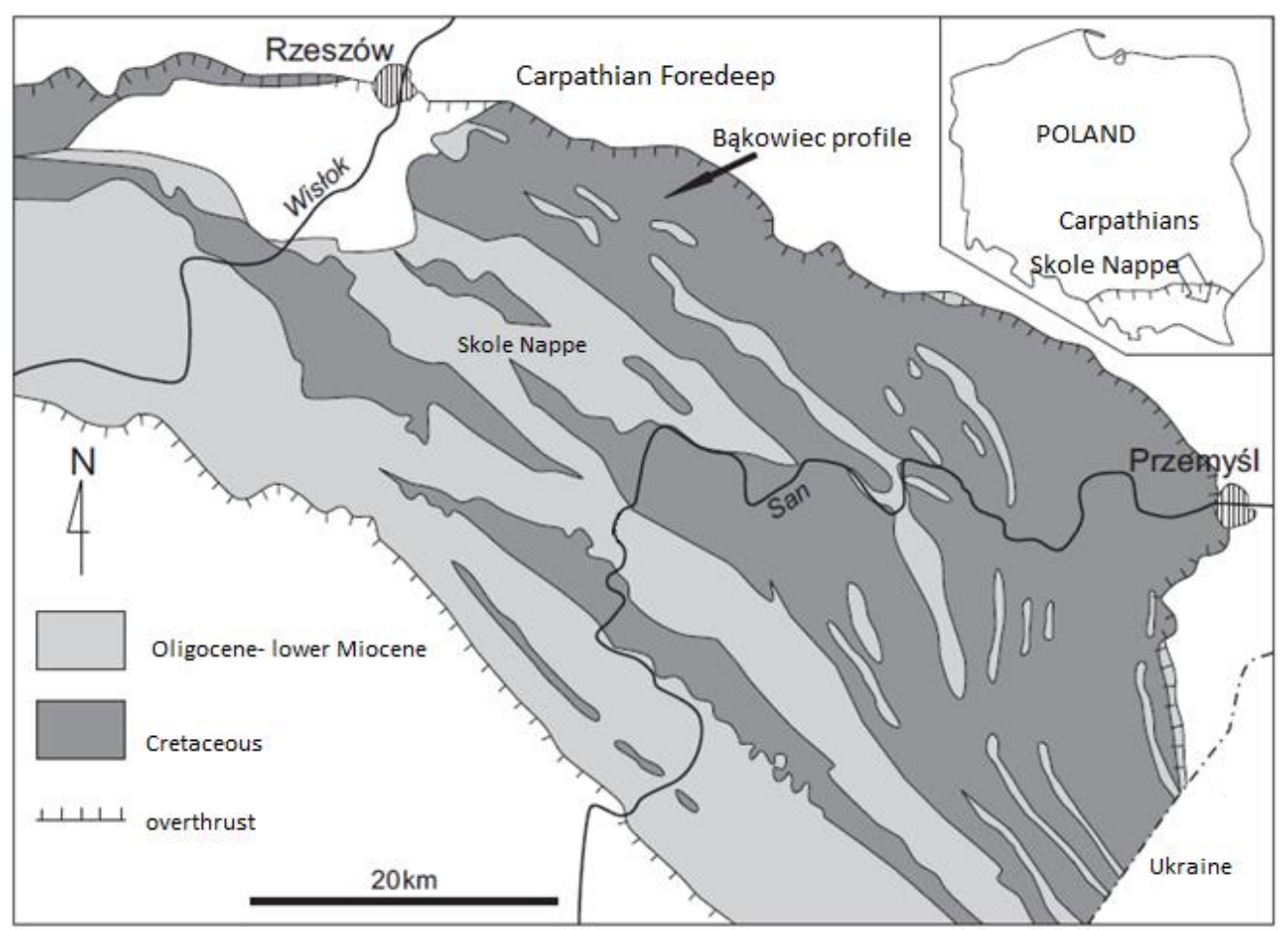

Fig. 1. Location of Bąkowiec section [5]

The studied area is located in the Outer Carpathians, more precisely it is situated near the front of the Skole Nappe. Sediments of the CPB are represented by calcareous sandstones and shales of the Ropianka Formation, in older literature called Inoceramic Beds[9][7].

\section{Methods:}

Within the marl layers, 10 samples were collected, each weighing about $0.5 \mathrm{~kg}$ to tests for the presence of spherules. These samples were named in sequence: BAK400, BAK401, BAK402, BAK403, BAK404, BAK405, BAK406, BAK407, BAK408, BAK409. [Fig. 2.] 


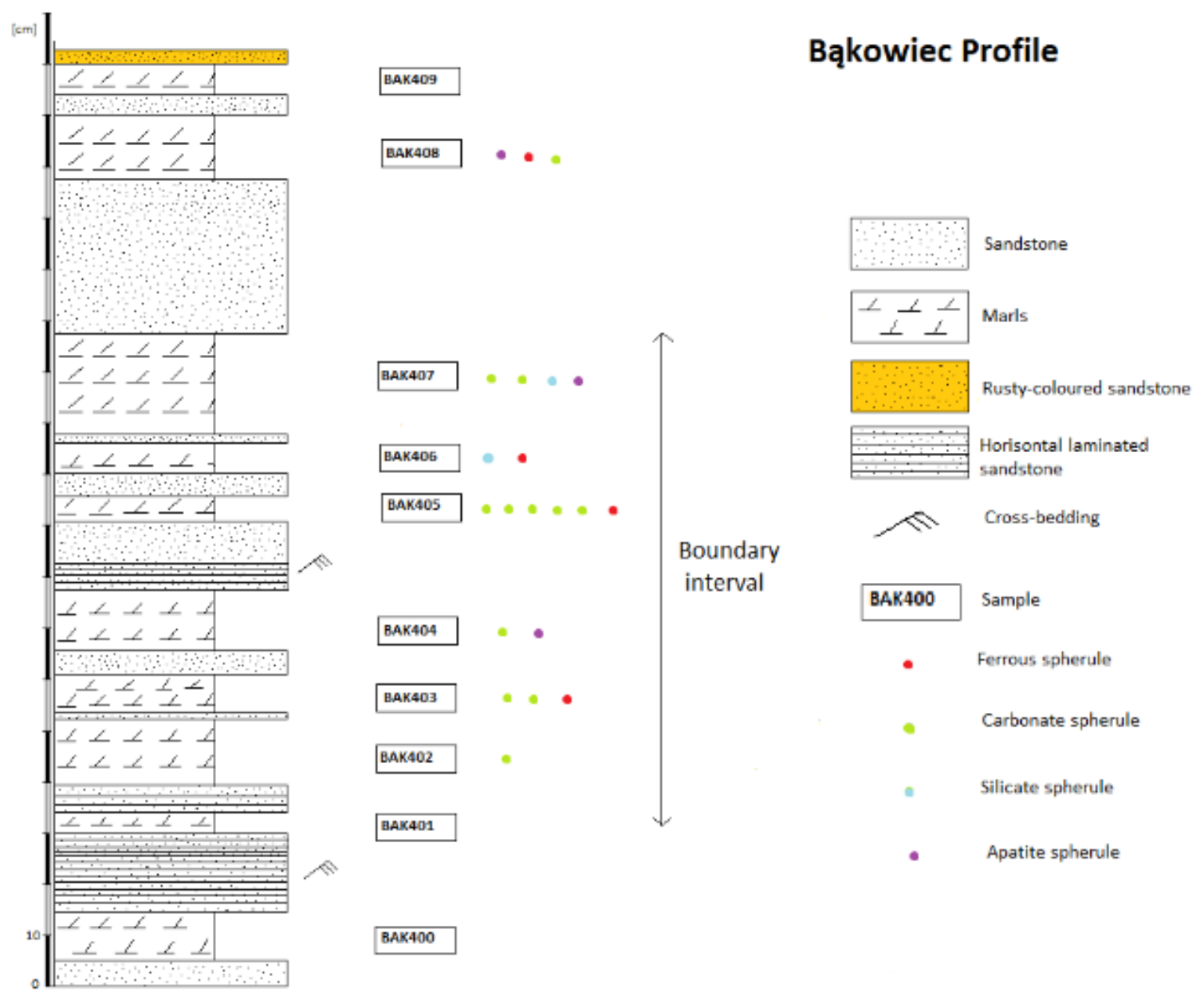

Fig. 2. Bąkowiec Profile. Collected samples and found spherules are marked. Boundary interval determined according to [5].

Every sample was sifted on a sieve with a mesh thickness of $0.054 \mu \mathrm{m}$ and the obtained, dried material was poured into paper envelopes. After that, manual separation of spheres using a magnifying binocular glass was undertaken at 20-fold and thirty-fold magnification. Alleged spheres were separated. During separation, a spherical shape, smooth and glassy surface and dissimilarity from other components was guided. In further part of the work, all isolated particles are called spherules.

Subsequently, the spherules were tested in the HITACHI S-4700 microscopewith the NORAN Vantage microanalysis system at the Laboratory of Scanning Microscopy in the Institute of Geological Sciences of Jagiellonian University. The spherules intended for testing were placed on the coal disc and covered with a layer of coal. The surface morphology of 21 spheres and their chemical composition was obtained. 


\section{Results and Discussion:}

There are heterogeneous 4 groups of spherules that are differing in chemical composition. the 21 examined particles include: 12 carbonate, 4 ferrous, 3 apatite and 2 silicate spheres.

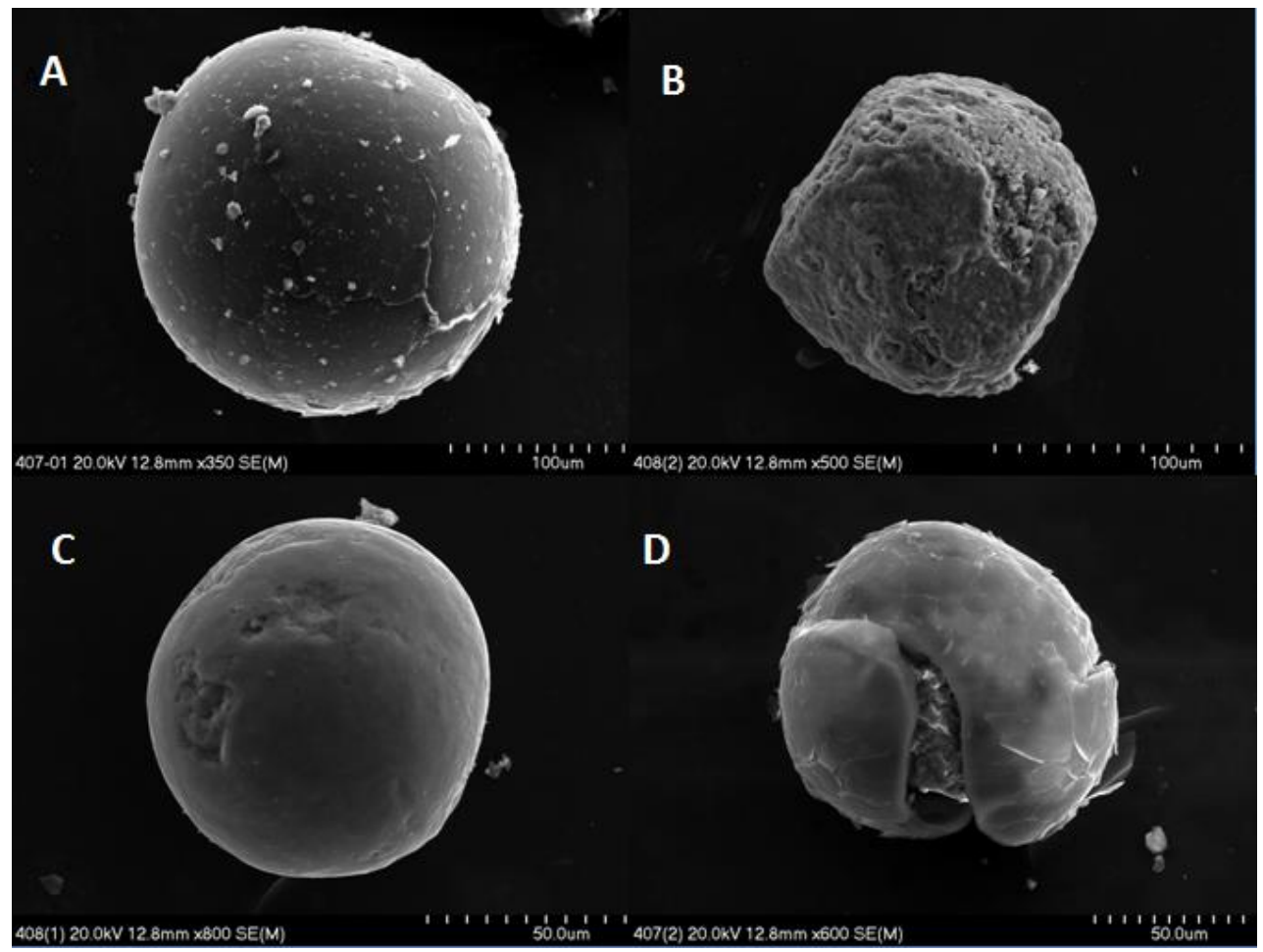

Fig. 3. Spherules from the Bąkowiec profile. A-carbonate spherules, B- ferrous "spherules", Capatite spherules, D-silicatespherules.

Carbonate spherules are black, red and yellow, composed mainly of calcium carbonate. They are about $200 \mu \mathrm{m}$ in size and have a smooth surface. [Fig. 3A]

Ferrous "spherules" are distinguished by their roughnesssurface. [Fig. 3B] They have a red color derived from oxidized iron. Spherules are different because of less spherical rather angularshape and size about $100 \mu \mathrm{m}$.

Apatite spherules are characterized by a large amount of apatite in their composition. They are not common. These particles are approximately $150 \mu \mathrm{m}$ in size and have a smooth surface. They havegrayish coloror they can be translucent. [Fig. 3C]

Spherules with a silicate composition content about $75 \%$ of $\mathrm{SiO} 2$, but the $\mathrm{CaO}$ content is also significant (16\%). Presented spherule has two-part structure, with a distinct core and outer rim. It has a size of about $100 \mu \mathrm{m}$ and irregular shape. The silicate spheres are the rarest spherules in the Bąkowiec profile. [Fig. 3D] 
The presence of spherules in the sediment may indicate that ejected dust has got into the sediment after the impact of the meteorite. The Cretaceous-Paleogene boundary age of studied interval, allows to link the founded spherules with a Chixculub impact. However, without any further researchers we cannot be absolutely sure. Chemical composition of this spherules does not coincide with the expected one, because they are not similar to any particles described in the literature.

\section{References:}

[1] Alvarez, L., Alvarez, W., Asaro, F., Michel, H., 1980. Extraterrestrial Cause for the CretaceousTertiary Extinction. Science, 208: 1095-1108.

[2] Antczak, M., 2014. Zagadka wymierania kredowego. Wszechświat, 115: 206-208.

[3] Brachaniec, T., Broszkiewicz, A., 2013. Problematyczność identyfikacji impaktu napodstawie geologicznych mikrośladów. ActaSocietatisMetheoriticaePolonorum, 4: 28-36.

[4] Collins, G. S., Melosh, H. J., Osinski, G.R., 2012. The Impact-Cratering Process.Elements, 8: 2530.

[5] Gasiński, M.A. \&Uchman, A., 2011. The Cretaceous-Paleogeneboundry in turbiditicdeposits identified to bed: a case study from the SkoleNappe (Outer Carpathians,southern Poland). GeologicaCarpathica, 62, 4: 333-343.

[6] Glass, B. P., Simonson, B.M, 2012. Distal Impact Ejecta Layers: Spherules and More. Elements, 8: 43-48.

[7] Kotlarczyk, J., 1988. Geologia Karpat przemyskich - „szkic do portretu“. Przeglad Geologiczny, 36: 325-333.

[8] Manecki, A., 2013. "Meteorytyka z elementami planetologii. Glosariusz". Mineralpress, Kraków, 26-28, 66-67 pp.

[9] Oszczypko, N., Ślączka, A., Żytko, K., 2008. Regionalizacja tektoniczna Polski- Karpaty zewnętrzne i zapadlisko przedkarpackie. PrzeglądGeologiczny, 56: 927-935

[10] Wedepohl, K. H., 1995. The composition of the Continental crust. Geochim. Cosmochim. Acta, 59: 1217-1232. 